\title{
CNBD1 Gene
}

National Cancer Institute

\section{Source}

National Cancer Institute. CNBD1 Gene. NCI Thesaurus. Code C143056.

This gene is involved in cyclic nucleotide binding. 